\title{
La perspectiva artística de la violencia social en México en el último siglo
}

\author{
Alma Barbosa Sánchez \\ Universidad Autónoma Metropolitana, Iztapalapa \\ lunatzin@yahoo.com
}

\begin{abstract}
Resumen
La violencia social ha constituido una temática recurrente en el arte mexicano desde la década de los años 1920 hasta la actualidad. Interpretando periodos históricos marcados por el conflicto social, los artistas han descrito la victimización social como resultado de la confrontación de fuerzas políticas hegemónicas y subalternas. Con una perspectiva histórica, la pintura mural y la gráfica artística han representado la violencia social que se origina en la conquista ibérica de las colectividades indígenas, la confrontación entre la oligarquía terrateniente y el movimiento campesino durante la Revolución Mexicana, la coerción del Estado contra los disidentes sociales en la era posrevolucionaria y la actual "guerra" contra la población, como resultado de la praxis de los grupos criminales de narcotraficantes y de la corrupción gubernamental. De ahí la pertinencia de exponer brevemente los momentos más relevantes de la representación artística de la violencia social en México y destacar la obra gráfica del artista Emiliano Martínez Guerrero (1988), por ejemplificar la perspectiva simbólica de la representación de las sangrientas circunstancias que actualmente padece la sociedad mexicana.
\end{abstract}

\section{Palabras clave}

México, arte, social, violencia, representación.

\section{A perspectiva artística da violência social no México no último século}

\begin{abstract}
Resumo
A violência social tem constituído uma temática recorrente na arte mexicana, desde a década dos anos 1920 até a atualidade. Interpretando períodos históricos caracterizados por o conflito social, os artistas têm descrito a vitimização social como resultado da confrontação de forças políticas hegemônicas e subalternas. Com uma perspectiva histórica, a pintura mural e a gravura artística têm representado a violência social que se origina na conquista ibérica das comunidades indígenas, na confrontação entre a oligarquia latifundiária e o movimento camponês durante a Revolução Mexicana, na coerção do Estado sobre os dissidentes sociais na era pósrevolucionária e na atual "guerra" contra a população, como resultado da práxis de grupos criminosos traficantes de drogas e da corrupção do governo. Daí a pertinência de expor brevemente os momentos mais marcantes da representação artística da violência social no México, e de realçar o trabalho gráfico do artista Emiliano Martínez Guerrero (1988), por exemplificar a perspectiva simbólica da representação das circunstâncias sangrentas que sofre atualmente a sociedade mexicana.
\end{abstract}




\title{
Palavras chave
}

México; arte; social; violência; representação.

\section{Social violence in Mexico from the perspective of art in the last century}

\begin{abstract}
Social violence has been a recurring theme in Mexican art from the 1920s to the present. Interpreting historical periods marked by social conflict, artists have described social victimization as a result of the confrontation between hegemonic and subaltern political forces. With a historical perspective, mural paintings and graphic arts have represented the social violence that originated in the Iberian conquest of indigenous communities; the confrontation between the landed oligarchy and the peasant movement during the Mexican Revolution; the coercion of the State against the social dissidents in the post-revolutionary era; and the current "war" against the population, as a result of the praxis of drug cartels and government corruption. In this article, we briefly present the most relevant moments of artistic representations of social violence in Mexico. We highlight the graphic work of artist Emiliano Martínez Guerrero (1988) as an example of representing the symbolic perspective of the bloody circumstances which Mexican society currently endures.
\end{abstract}

\section{Keywords}

Mexico, art, social, violence, representation. 


\section{Introducción}

En el arte mexicano, la violencia social ha sido objeto de numerosas representaciones durante el siglo XX y hasta la actualidad. En distintos periodos históricos, los artistas han interpretado la temática de la violencia social que engendra el conflicto político entre los gobiernos y sectores de la sociedad civil. En la primera mitad del siglo pasado, el muralismo mexicano y la estampa del Taller de Gráfica Popular ${ }^{1}$ representaron e interpretaron el conflicto social de acuerdo a la perspectiva política marxista, que justifica el recurso de la violencia revolucionaria en defensa de los derechos sociales de la población. En el periodo de 1960-1980, el movimiento estudiantil de 1968, el Grupo Proceso Pentágono y los artistas Melecio Galván y José Antonio Hernández, en particular, denunciaron y exhibieron, en sus obras gráficas y conceptuales, la violencia represiva del Estado mexicano. En la actualidad, el artista Emiliano Martínez Guerrero (1988) interpreta simbólica y gráficamente la violencia terrorista que practican los grupos criminales del narcotráfico, a partir de la guerra emprendida en su contra por el gobierno del expresidente Felipe Calderón (2006-2012). Mientras otros artistas mexicanos enfatizan la condición de las víctimas de los narcotraficantes, en su representación de la violencia actual², Emiliano Martínez Guerrero plantea una interpretación gráfica de la deshumanización de los victimarios y su profesionalización en la utilización de técnicas de degradación del cuerpo post mortem de sus víctimas.

En general, el proceso de representación artística se ha fundamentado en la descripción de un hecho social que involucra el sometimiento de la sociedad civil, a través de la actuación de los aparatos coercitivos del Estado y de los grupos criminales. De acuerdo con las circunstancias del contexto histórico y la ideología de los artistas, la violencia social ha sido interpretada con un carácter revolucionario ante las injusticias sociales o como denuncia y testimonio de la represión gubernamental y del terrorismo de los grupos criminales del narcotráfico. De esta manera, los artistas han utilizado el poder simbólico de las imágenes para ofrecer un discurso visual de crítica política que involucra un desafío al statu quo. Desde un punto de vista sociológico, la violencia social ${ }^{3}$ es el resultado de las estructuras políticas y sociales que propician su manifestación en distintos contextos histórico. De ahí que, en el examen de su representación e interpretación artística, se

1. Entre los integrantes del Taller de Gráfica Popular se encuentran Leopoldo Méndez, Pablo O'Higgins, Raúl Anguiano, Luis Arenal, Ángel Bracho, Xavier Guerrero, Luis Arenal, Ignacio Aguirre, Francisco Dosamantes, Raúl Gamboa, Antonio Pujol, José Chávez Morado, Gonzalo de la Paz Pérez y Alfredo Zalce, Fanny Rabel, Alberto Beltrán, entre muchos otros (Prignitz-Poda, 1992:14).

2. Véanse las obras de Teresa Margolles, Alfonso Zárate, Rosa María Robles, por ejemplo.

3. "El problema de la violencia, desde una perspectiva teórica, debe incorporar una amplia visión de campo que parta de una reflexión que involucre la relación entre las condicionantes estructurales que 'impulsan' a los escenarios de violencia, como a destacar, también, la posición del individuo que actúa como sujeto y que ha evaluado su decisión de actuar de esa manera. Ambas perspectivas se encuentran, hoy en día, a debate y la sociología busca integrarlas de alguna forma" (Arteaga Botello, 2003: 132). 
adopten la perspectiva diacrónica y el análisis denotativo y connotativo de obras representativas de tres modalidades de violencia social: revolucionaria marxista, de Estado y terrorista del narcotráfico.

\section{Violencia revolucionaria}

Durante las primeras décadas del siglo XX, el muralismo mexicano inauguró el discurso político del conflicto social. Interpretando la biografía del país, ilustró que los estallidos de violencia social forman parte de la constante reinvención de la sociedad mexicana, en distintos periodos históricos. Desde 1923, los muralistas mexicanos gozaron de plena libertad para representar la postura indigenista, nacionalista y socialista del conflicto político. El francés Jean Charlot, fue precursor en representar la perspectiva indigenista de la violencia social. En su obra Masacre en el Templo Mayor (Escuela Nacional Preparatoria, 1923) ilustró la praxis homicida que padecieron las colectividades indígenas a manos de los conquistadores españoles. El artista afirma que: "presentó por primera vez en un muro a los personajes de un drama -caballeros robots pisoteando víctimas indígenas- que merecería muchas repeticiones posteriormente" (Charlot, 1985: 186).

Con una postura nacionalista, José Clemente Orozco ilustró la pertinencia histórica de la Revolución Mexicana, que permitió la reconstrucción política del país a través de la aspiración de justicia social. En los murales de la Escuela Nacional Preparatoria (La trinchera, Revolucionarios, La huelga, Destrucción de viejo orden, El banquete de los ricos, Cortés y la Malinche, 1923-1927), este artista representó la violencia social que se gestó durante la movilización armada de campesinos y trabajadores contra la dictadura de Porfirio Díaz (1876-1911). Particularmente, su obra La trinchera resulta emblemática por representar el drama de tres personajes campesinos que desfallecen en la desesperada defensa de su lugar de resguardo. En opinión de Raquel Tibol, "sus obras llevaran el sello del contra-gemido; él será la entraña de su pueblo convulso por la amargura. Nadie podrá decir jamás que México no lloró su desgracia; la obra de Orozco es el gran llanto de histórico surgido de la rebeldía y también de las frustraciones de un pueblo. Fue ese caudal de dolor comunitario el que alimento su fantasía" (1981:251).

Pictóricamente, Diego Rivera y David Alfaro Siqueiros ${ }^{4}$ adoptaron la interpretación marxista del conflicto social y reivindicaron el recurso de la violencia revolucionaria, como respuesta a las injusticias sociales. Como señala Michel Foucault, toda postura revolucionaria invoca la necesidad de transformación del statu quo, por lo cual opone la violencia revolucionaria a un orden social que también se fundamenta en la violencia económica y política:

4. David Alfaro Siqueiros representó la violencia social en su obra Tormento de Cuauhtémoc (1950), que describió al último emperador del México precolombino, mientras era torturado por los españoles. En sus obras Víctimas de la guerra y Víctimas del fascismo, 1945) denostó la guerra y el fascismo. 
Después de todo, ¿qué significarían, qué podrían ser la idea y el proyecto revolucionarios, en primer lugar, sin ese desciframiento de las disimetrías, los desequilibrios, las injusticias y las violencias que funcionan a pesar del orden de las leyes, bajo el orden de las leyes, a través de y gracias al orden de las leyes? ¿Qué serían la idea, la práctica y el proyecto revolucionarios sin la voluntad de sacar a la luz una guerra real, que se desarrolló y sigue desarrollándose, pero que el orden silencioso del poder tiene por función e interés, precisamente, sofocar y enmascarar? ¿Qué serían la práctica, el proyecto y el discurso revolucionarios sin la voluntad de reactivar esa guerra a través de un saber histórico preciso y sin la utilización de ese saber como instrumento en ella y como elementó táctico dentro de la guerra real que se libra? ¿Qué significarían el proyecto y el discurso revolucionarios sin la mira de cierta inversión final de la relación de las fuerzas y el desplazamiento definitivo en el ejercicio del poder? (Foucault: 2001: 78-79).

Diego Rivera, el más prolífico de los muralistas, llevó a su máxima exaltación pictórica la interpretación marxista del conflicto social. Simbolizó la dinámica de la economía capitalista, representando la sistemática explotación de los trabajadores en las minas, las faenas agrícolas y la industria. En su obra Distribución de armas (Secretaria de Educación Pública, 1928) abogó por la movilización armada de la población, acorde a la defensa revolucionaria de sus derechos políticos y económicos. Consecuentemente, representó la alianza política de obreros, campesinos, soldados, niños y mujeres contra el sistema capitalista. En primer plano, la figura de Frida Kahlo destaca por repartir las armas que servirán a la revolución proletaria, mientras ondea una bandera con el símbolo comunista. Más aún, celebrando la utopía socialista, Rivera exaltó pictóricamente la figura de Carlos Marx, en la máxima sede simbólica del Estado mexicano: el Palacio Nacional.

Cabe mencionar que, durante el periodo de 1920-1940, la tolerancia gubernamental a la exaltación muralista de las tesis marxistas obedeció al interés de la clase política de legitimarse ideológicamente recurriendo a la retórica nacionalista, revolucionaria y, también, socialista. Discursivamente, los gobernantes atribuyeron a la noción de socialismo una significación sui géneris o ajena a las teorías marxistas, considerando que las reformas sociales posrevolucionarias merecían definirse como "socialistas" por atender el interés de las mayorías. Baste mencionar que, en 1923, la prensa consignó la filiación "socialista" de Plutarco Elías Calles, a través de su compromiso con las demandas de los sectores populares, durante su campaña electoral a la presidencia:

Ya como presidente, no hesitó en seguir utilizando esta misma retórica [socialista] hasta el punto de habérsele conocido como el "presidente rojo". Sus colaboradores cercanos -Manuel Puig Casauranc, Luis L. León, Luis Napoleón Morones, Marte R. Gómez, Víctor Manuel Villaseñor, Ramón P. Denegrí- mostraron también interés por el proceso soviético (Urías Horcasitas, 2005: 269).

Sin duda, los gobiernos posrevolucionarios manifestaron capacidad de asimilar los relatos murales a su retórica "socialista", que fue utilizada como un recurso propagandístico y cultural, para legitimar su papel como promotores de las reformas sociales. 
A finales de los 1930, la interpretación marxista del conflicto social se manifestó en la gráfica artística a través del Taller de Gráfica Popular (TGP, 1937). Desde un principio, los integrantes del TGP adoptaron la organización autogestionaria y el trabajo colectivo en la producción de la estampa política. Su narrativa gráfica se caracterizó por la interpretación nacionalista, histórica y marxista de la sociedad mexicana. Ilustró el conflicto político en los distintos periodos históricos del país y exaltó la movilización de los trabajadores y campesinos en defensa de sus derechos laborales. Así también, ofreció la crónica grafica de los acontecimientos relevantes de su época, como la gestión nacionalista del gobierno de Lázaro Cárdenas (1934-1940) -que promovió la educación socialista y la expropiación petrolera-, la lucha antifascista y la movilización armada de los grupos católicos (cristeros), entre otros. Un ejemplo de su postura antifascista es la estampa del artista Alberto Beltrán en la cual se ve la figura de perfil del presidente Lázaro Cárdenas señalando con el dedo índice el horizonte, donde un conjunto de militares nazis de aspecto oscuro y siniestro acribillan a un combatiente republicano. En la parte inferior derecha de la composición se ubica la pequeña figura caricaturizada de Francisco Franco, observando la escena (Estampas de la Revolución Mexicana, 1947). En la carpeta litográfica En nombre de Cristo... han asesinado a más de 200 maestros (1939), Leopoldo Méndez ilustró con sumo realismo los asesinatos de varios maestros rurales perpetrados por grupos católicos (cristeros) en contra de su labor educativa. Cada imagen consignó el nombre del maestro y las circunstancias de su asesinato; y se acompañó de un pequeño texto que reproducía la información de la prensa o de las instituciones oficiales y sindicales sobre los hechos ocurridos.

Leonor Morales afirma que los artistas del TGP "coincidieron con el realismo socialista en las representaciones apegadas a la realidad revolucionaria para educar a las masas dentro del socialismo" (1992: 220). De ahí que sus estampas asumieran una función ideológica revolucionaria ante el conflicto social, como ilustra el testimonio de Leopoldo Méndez:

La coordinación de nuestros esfuerzos, la discusión colectiva de los problemas inmediatos, de la táctica y estrategia del movimiento revolucionario y de las perspectivas de la Revolución Mexicana, permitirán al marxismo mexicano jugar un papel decisivo en la unificación, depuración y democratización del movimiento sindical y campesino y en la del frente revolucionarlo antiimperialista y antifeudal (Méndez en Híjar, 2018: 16).

Es patente que, en las primeras décadas del siglo XX mexicano, el contexto histórico fue favorable a la libertad de expresión de los artistas que interpretaron el conflicto político desde la perspectiva marxista, toda vez que la clase política capitalizó discursivamente la efervescencia revolucionaria de la época mediante a noción de socialismo. En estas circunstancias, el muralismo mexicano fue precursor del discurso nacionalista, indigenista y político en el continente americano. 


\section{La violencia de Estado}

A partir de los 1960, los artistas denunciaron en sus obras el carácter antidemocrático del sistema político mexicano que, a través del régimen de partido único (Partido Revolucionario Institucional) y el autoritarismo presidencial, limitó la dinámica democrática en el país. Cuando el movimiento estudiantil de 1968 exigió el derecho a disentir públicamente de las decisiones gubernamentales, fue reprimido mediante la masacre de estudiantes en la Plaza de Tlatelolco el día 2 de octubre. El acto criminal cobró notoriedad internacional por perpetrarse durante la celebración de los Juegos Olímpicos en México.

Consecuentemente, la violencia de Estado fue objeto de representación artística mediante la gráfica del movimiento estudiantil de 1968. En respuesta a la política represiva del gobierno, alumnos de la Academia de San Carlos y de la Escuela Nacional de Pintura, Escultura y Grabado La Esmeralda, así como artistas afines, emprendieron una campaña de comunicación social con el propósito de informar a la opinión pública sobre la legitimidad de su movilización democrática. A través de volantes y carteles, desarrollaron un discurso gráfico que censuró y denunció la ilegalidad de las prácticas represivas gubernamentales. Desde el espacio público, la estampa constituyó un recurso primordial en la estrategia estudiantil de comunicación social con la población, como lo había sido durante el mes de mayo en Francia. En efecto, las cualidades técnicas de la gráfica resultaron sumamente pertinentes no sólo en la argumentación visual del movimiento estudiantil mexicano, sino también en la protesta estudiantil francesa, toda vez que:

Los carteles fueron realizados por estudiantes, profesores y trabajadores en talleres improvisados y, en el caso de París, en los talleres ocupados de la Escuela de Bellas Artes, en las distintas facultades o en agrupaciones de barrio. Durante el mayo francés, sólo en los talleres de la Escuela de Bellas Artes se editaron alrededor de 500 mil carteles con unos 400 motivos diferentes" (Tejeda, 2018).

Incluso, la sangrienta represión de los estudiantes mexicanos fue registrada por la gráfica estudiantil francesa: "hay varios carteles parisinos o franceses que hacen alusión directa a lo que ocurrió en México en octubre de 1968: la matanza de estudiantes en la plaza de las Tres Culturas de Tlatelolco y la reacción furibunda del Estado mexicano por ocultar un hecho tan dramático y grave en la inauguración de los Juegos Olímpicos" (Tejeda, 2018).

Así fue como, en el contexto mexicano, los artistas utilizaron para sus propios fines de denuncia política de la violencia de Estado el diseño, la tipografía, los logotipos y los lemas oficiales con los que el gobierno publicitó la celebración de las Olimpiadas, para descontextualizarlos y resignificarlos. Por ejemplo, los logotipos oficiales distintivos de actividades olímpicas como la natación, la esgrima o la gimnasia fueron resignificados por los artistas, al sustituir sus figuras por otras 
alusivas a la represión castrense, como la bota militar, el tanque, el fusil, el soldado, etc. De este modo, la gráfica estudiantil demostró su competencia para debatir iconográficamente con la propaganda gubernamental y constituir una publicidad alternativa a la oficial, con significaciones disidentes que denunciaron la violencia y el autoritarismo del sistema político mexicano, así como la ilegalidad de sus acciones represivas.

Con posterioridad a los eventos de 1968, el contexto de persecución y clandestinidad fue determinante para que los artistas recurrieran a la experimentación de una retórica visual convincente y testimonial, así como a la improvisación de técnicas de impresión. La imagen gráfica y el texto, como soportes lingüísticos, constituyeron una fórmula doblemente elocuente y eficaz de argumentación visual para desacralizar la figura presidencial, evidenciar el papel represivo del ejército y exhibir la incongruencia del sistema político mexicano, el que, hasta entonces, parecía incuestionable. Un cartel emblemático fue el de la representación del perfil de un gorila portando un casco militar. A su vez, esta figura contenía el perfil del expresidente represor: Gustavo Díaz Ordaz. La imagen se acompañó con el texto: "México 68", utilizando la tipografía oficial de la campaña gubernamental de promoción de las Olimpiadas. La argumentación visual planteó dos analogías; la primera, entre la figura del primate -que connota precariedad racional por antonomasia-y la del Ejército mexicano; la segunda, entre la del gorila y la del expresidente, por su sobrada capacidad de reprimir, antes que de dialogar razonadamente. Así también, los artistas representaron la figura de un imponente tanque militar que, frontalmente, avanza hacia el espectador. El soporte textual argumentó: "Este diálogo no lo entendemos". Conviene recordar que, en el mes de julio de 1968, el Ejército y la Policía ocuparon el Instituto Politécnico Nacional, con un saldo de centenares de heridos y docenas de estudiantes muertos. En septiembre, la Universidad Nacional Autónoma de México fue tomada por las tropas militares. Y en octubre, ocurrió la masacre de estudiantes, en la Plaza de Tlatelolco.

A partir de entonces, el arte político cobró impulso, con la finalidad de describir y denunciar la violencia de Estado, así como la problemática social de la época. A la vez, propició la integración de los artistas en diversos grupos de trabajo colectivo: Tepito Arte Acá, Grupo Proceso Pentágono, Mira, Suma, Taller de Arte e Ideología, Tetraedro, Taller de Investigación Plástica, El Colectivo, Germinal, Fotógrafos Independientes, Peyote y la Compañía, Março, No Grupo, El Taco de la Perra Brava.

Durante 1970, el sistema político mexicano reiteró su praxis represiva mediante la masacre de estudiantes (1971), la violenta agresión al movimiento sindical independiente de electricistas (1976) y su respuesta militar a la guerrilla rural de filiación marxista. En este contexto, destacó el Grupo Proceso Pentágono, integrado por Felipe Ehrenberg, Víctor Muñoz, Carlos Finck y José Antonio Hernández, por representar la violencia del Estado en México y América Latina mediante los 
lenguajes del arte conceptualista ${ }^{5}$ que, en ese momento, resultaban novedosos en el escenario artístico mexicano.

En 1977, el Grupo Proceso Pentágono participó en la X Bienal de Jóvenes de París con la instalación Pentágono, que simbolizó la represión y tortura a los disidentes sociales. La instalación consistió en una estructura de madera de $3.70 \mathrm{x}$ $2 \mathrm{~m}$ que ocupó una superficie de $7.4 \mathrm{~m}^{2}$. Por su forma, connotó el edificio norteamericano denominado Pentágono, sede del Departamento de Defensa de los Estados Unidos y donde se alberga información político-militar sobre los países latinoamericanos. En los muros exteriores, se utilizaron imágenes seriadas de campesinos y soldados. Alrededor de la estructura, una cenefa pictórica simulaba un tablero electrónico con un texto lingüístico: "Bannana, Gol". La primera palabra connotó la exportación y cotización de las materias primas latinoamericanas en la bolsa de valores internacional; la segunda, la distracción de las masas por el fútbol y el triunfo parcial en este deporte. Frente a la instalación, se colocó una figura presumiblemente humana -envuelta a la manera de un bulto-que representó a los "desaparecidos" políticos ${ }^{6}$.

El espacio exterior e interior de la instalación connotaron dos aspectos de la biografía territorial y social de México y América Latina. El espacio exterior simbolizó el contexto de la economía internacional y la desigualdad entre países industriales y dependientes (agroexportadores); el interior, las prácticas ilícitas y clandestinas de los gobiernos latinoamericanos, como la tortura a los disidentes sociales. En él, los artistas colocaron diversos objetos, como mesas y sillas - pintadas de color verde olivo y codificadas con la numeración propia de los inventarios militares- que simbolizaron la infraestructura y el mobiliario del aparato represivo. Sobre uno de los muros, se colocaron un dispositivo y cables eléctricos que se orientaban hacia una silla; junto a ésta, se hallaban bolsas de plástico. La silla connotó la posición ocupada por un detenido político; los cables y las bolsas de plásticos remitieron a

5. Durante su trayectoria artística, el Grupo Proceso Pentágono se caracterizó por las instalaciones, ambientaciones y performances. En opinión de Pilar García “El Grupo Proceso Pentágono en particular pugnó por renovar la relación con el sistema del arte (instituciones y galerías) en un contexto social y político represivo. Con un lenguaje ligado a los conceptualismos e interés por la experimentación y la búsqueda de nuevos formatos y lenguajes de expresión, realizaron un trabajo colectivo" (2016: 21). Cabe recordar que, desde Marcel Duchamp hasta Yves Klein, John Cage, Joseph Kosuth, Joseph Beuys, entre otros, en Europa y Estados Unidos, se confrontó al objeto artístico tradicional a través de la experiencia y el sentido conceptual de la obra. De esta manera, las prácticas artísticas adquirieron un estatus conceptual y efímero a través de los fundamentos del "arte como idea" y el "arte como acción". En la década de los 1960, la emergencia del performance (arte acción), el body art (arte del cuerpo), el mail art (arte correo) confirmaron el proceso de deconstrucción del objeto artístico convencional. Marchán Fiz (1994: 12) señala: "Si en el arte tradicional predominaba el objeto sobre la teoría, en el modelo sintáctico-semántico desde la 'abstracción' se da un equilibrio, hasta abocar a situaciones límites -como en el arte conceptual-, donde prevalece la teoría sobre el objeto. Ya no se basta la obra, sino que debe enmarcarse en las teorías que la fundamentan".

6. El concepto de "desaparecido" político remite al arresto, la detención, el secuestro o cualquier otra forma de privación de libertad que sea obra de agentes del Estado o de personas o grupos de personas que actúan con la autorización, el apoyo o la aquiescencia del Estado. 
la tortura que se ejecutaba mediante electricidad y por asfixia. Sobre una mesa, botellas de licor representaron los hábitos de los torturadores. En los muros, unos conjuntos de casilleros de madera contenían diversos objetos e imágenes que simbolizaron la dinámica de la violencia social de la época, como, por ejemplo, pequeñas esculturas de yeso con formas humanas (mano, pie, oreja), artefactos punzocortantes (navajas y hojas de afeitar), fotografías, mapas de la República Mexicana en distintas posiciones, una gorra militar y recortes de periódicos. La dinámica interactiva de la instalación permitió al público recorrer el espacio interior y alterar la disposición original de los objetos. De esta manera, los artistas utilizaron diferentes códigos espaciales, temporales, icónicos, textuales y objetuales para construir metáforas de la violencia de Estado engendrada en el contexto mexicano y latinoamericano.

De manera individual, José Antonio Hernández exhibió la instalación "La calle" dentro de la exposición titulada Nivel Informativo o Tres informaciones, Tres (Palacio de Bellas Artes, 1973)- que simbolizó la represión policiaca contra los disidentes sociales que realizaban "pintas", esto es, que plasmaban consignas políticas sobre los muros de las edificaciones, en el espacio urbano. La obra consistió en un muro de grandes dimensiones donde el artista plasmó con grandes brochazos de pintura: "Libertad pr...", en alusión a la demanda y consigna de ese entonces: "Libertad presos políticos". Este recurso visual constituyó una cita de la "pinta" callejera que se complementó con la secuencia de figuras humanas huyendo, un bote de pintura colocado en el piso y marcas de proyectiles balísticos sobre el muro.

En los 1980, las políticas neoliberales impusieron la acelerada privatización de los bienes nacionales y la represión social, mientras que las organizaciones de derechos humanos cobraban protagonismo, en México, por denunciar los abusos policiacos y del ejército contra la población civil. En este contexto, la violencia de los aparatos represivos del Estado mexicano fue objeto de representación simbólica en la obra gráfica Militarismo y represión (1980), del artista Melecio Galván (1945-1982).

En su retórica gráfica, Galván subrayó la deshumanización que involucra la praxis de los miembros de la policía y del ejército a través de metáforas del cuerpo humano en simbiosis con partes del cuerpo de distintos animales: simios, rinocerontes, escorpiones, entre otros (Aquino, 1995: 350). Así también, representó la simbiosis de los cuerpos de los represores con los dispositivos propios de las máquinas:

Si los personajes que componen el teatro trágico de la obra de Galván aglutinan mayores referencias a la muerte que a la vida, aluden más al crimen que a la alegría, tal panel de sombras se manifiesta en esa suerte de operación quirúrgica desquiciante que es cada rostro, cada anatomía. Porque allí donde se desrealiza una fisonomía humana no se edifica la de un animal; ambas, por el contrario, nacen y agonizan articuladas en un cruento aflorar de vísceras, pústulas y protuberancias informes, muchas veces encadenadas a férreos dispositivos metálicos (Driben, 1992:45). 
En una de sus obras, Galván ilustró las figuras de dos militares mostrando parte de su estructura ósea debajo de sus trajes castrenses. Una de las figuras porta una mascarilla con tubos anillados que se engendran en su cuerpo. La metáfora visual plantea la deshumanización de la praxis militar y policiaca como maquinaria de represión social. Connota la capacidad gubernamental para utilizar el cuerpo del soldado, del policía, como "objeto del poder, al que se manipula, al que se da forma, que se educa, que obedece, que responde, que se vuelve hábil" en la praxis de reprimir o exterminar al adversario; en suma, el hombre-máquina, el autómata social inscrito en una relación utilidad-docilidad:

[Desde la] segunda mitad del siglo XVIII: el soldado se ha convertido en algo que se fabrica; de una pasta informe, de un cuerpo inepto, se ha hecho la máquina que se necesitaba; se han corregido poco a poco las posturas; lentamente, una coacción calculada recorre cada parte del cuerpo, lo domina, pliega el conjunto, lo vuelve perpetuamente disponible, y se prolonga, en silencio, en el automatismo de los hábitos (Foucault, 2002: 124).

Galván abordó el tema de la tortura a través de la figuración de dos siniestros personajes que flagelan y someten el cuerpo de un personaje que porta una corona de espinas, connotando la figura de Cristo. Así, remite al espectador a la praxis histórica de la violencia social. Sin duda, la poética gráfica de este artista resulta sumamente impactante por sus cualidades técnicas, aunadas a la representación e interpretación simbólica de la violencia de Estado, en el contexto mexicano. Desafortunadamente, a los 37 años y en plenitud creativa, el 29 de mayo de 1982, Galván fue asesinado, presuntamente, por agentes policiacos. Su cuerpo fue encontrado colgado de un poste de luz, con las manos destrozadas y el cuerpo ensangrentado. Hasta hoy su asesinato no ha sido aclarado. Cabe mencionar que la representación artística de la violencia en México no involucra necesariamente una represión gubernamental que atente contra los artistas, pese a que se han dado casos excepcionales, como el de David Alfaro Siqueiros, quien fue acusado del delito de disolución social y encarcelado por el expresidente Adolfo López Mateos (1958-1964).

\section{La violencia terrorista del narcotráfico}

A partir de la guerra contra el narcotráfico que emprendió el expresidente Felipe Calderón (2006-2012), la violencia contra la población y la violación de los derechos humanos se incrementaron a niveles extremos. Desde entonces, cobró protagonismo la violencia terrorista de los grupos criminales, a través de la praxis de abandonar en el espacio público los cuerpos desmembrados de sus víctimas y de exhibir cuerpos ahorcados, con la función de evidenciar su impunidad y el fracaso o la complicidad del Estado mexicano en esta guerra criminal.

Si en las guerras convencionales se cumple la finalidad de exterminio del adversario, en la "guerra" mexicana no basta con la muerte de la víctima, el cuerpo post 
mortem deja de constituir una unidad para reducirse a piezas de carne y huesos. Frecuentemente, las cabezas humanas se colocan en cajas y se abandonan en la vía pública, con la función de explicitar y transmitir el terror a la población. Así, "el espacio público devino necroteatro en el que se desplegaron iconografías del terror y la exhibición de la barbarie" (Diéguez Caballero, 2018: 204).

Para los deudos de las víctimas de la violencia criminal, la búsqueda de sus familiares constituye un reto constante, como describe el testimonio de un grupo de mujeres que, con sus propios medios, localizan restos humanos: "cuando encontramos restos, a todas nos da para abajo, nos sentimos tristes porque no queremos que sea nuestro hijo, y a la vez satisfechas porque pensamos que esa personita ya va a regresar a casa" (Díaz, 2017, p. 24). En opinión del líder social Rubén Sarabia Sánchez, "la situación de 'guerra' que vive el país fue creada y es utilizada por el gobierno para reprimir, en distintos niveles, los movimientos sociales y, con ello, generar una situación de miedo" (Rodríguez, 2017, p. 8). En este contexto, destaca la movilización de los familiares de las víctimas:

A la espectacularización de la muerte violenta en México, le ha seguido la sustracción y la invisibilización de los cuerpos, el despedazamiento atroz y su diseminación en fosas clandestinas, la reducción de los cuerpos a litros de un líquido viscoso, la desaparición de personas y el emprendimiento de sus búsquedas por grupos de familiares que han devenidos desenterradores, peritos y forenses por cuenta propia (Diéguez Caballero, 2018: 214).

En Tepic Nayarit, el 17 de abril de 2011, la prensa reportó el macabro hallazgo de un hombre a quien le había sido desprendida la piel: "Un cadáver desollado permanecía sentado junto al puente, de forma burlona y casi artística, los sicarios mutilaron las dos manos al ejecutado, una de ellas fue colocada en el pecho, la otra permanecía en el estómago, formando la señal de 'amor y paz'" (Diario Respuesta, 2011: 13). La escenificación criminal del homicidio involucra la profanación del cuerpo post mortem como un castigo más allá de la muerte, dramatizado en su exposición pública:

En el cuerpo, sobre todo, se trata de infringir dolor, de aplicar violencia extrema sobre la persona, reduciéndola a un objeto en el que se cristaliza el ejercicio del poder de una o varias personas. Es una especie de castigo que se inflige por algo que quizás se cree se ha cometido y que tiene que ser aplicado antes de privar a las personas de la vida. Una vez que se ha terminado con el sufrimiento del cuerpo, el castigo no termina ahí, la decapitación implica, por una parte, que la persona debe ser escarmentada más allá de la muerte. Lo cual implica, a diferencia de la ejecución tradicional como el llamado «tiro de gracia», un ejercicio más elaborado de la violencia que no sólo involucra el dar la muerte, sino alcanzarla a partir de un proceso de dramatización: es decir, montar una escena que muestre el resultado de la violencia y la crueldad ejercida (Arteaga Botello, 2009: 480).

Ciertamente, la violencia terrorista del narcotráfico ha sido objeto de representación artística mediante lenguajes del arte conceptual y, en menor medida, de la gráfica y la pintura, según consta en las obras de Teresa Margolles, Alfonso Zara- 
te, Rosa María Robles, Jorge Malacón, Emiliano Martínez Guerrero, Manuel Solís Mendoza, Gustavo Monroy, entre otros. La obra de Emiliano Martínez Guerrero cobra relevancia porque, a diferencia de los artistas que recurrentemente enfatizan la condición de las victimas del narcotráfico, este artista plantea una reflexión visual sobre la barbarie y la deshumanización que caracterizan a los victimarios. Captura el aspecto mórbido de los perpetradores de la violencia terrorista y su praxis de fragmentar los cuerpos de sus víctimas a través de la representación de la carne humana, como metáfora de una sociedad que se devora a sí misma.

En su obra Manducadores (Acuarela, 138 x 112 cm, 2016), Martínez Guerrero interpreta la violencia criminal o terrorista como una praxis de canibalismo social: el hombre devorado por el hombre, toda vez que ilustra un conjunto de cinco personajes masculinos que engullen carne humana, rodeados de fragmentos de huesos. En sus rostros desfigurados, dominan las exageradas dentaduras que enfatizan la actividad de engullir, destrozar. En primer plano, un personaje porta un sombrero con la pequeña imagen de la Virgen de Guadalupe, enfatizando el contexto mexicano. La fuerza expresiva de la figuración resulta notable por la excelencia técnica de su ejecución. Martínez Guerrero destaca la conceptualización de la metáfora gráfica del canibalismo social:

Dado que el consumo, la ingesta, engullir la carne se me hacía una muestra de salvajismo, de canibalismo. La apropiación, a través de consumir al otro. Por ejemplo, esto de las estructuras, los huesos, los nervios, incluso los dientes que ellos mismos muestran, remite todo ello a la tierra, a las estructuras básicas a lo que existe previo al cuerpo, dentro del cuerpo (comunicación personal, 28 de junio de 2017).

La ingesta de la carne humana como hábito de los grupos del narcotráfico resulta sumamente pertinente en la interpretación gráfica de este artista. El testimonio de un sicario confirma que parte de su entrenamiento consistía en comer carne humana: "un requisito para ver que no tenías miedo ante tu enemigo" (en Mauleón, 2018: 15).

En su poética gráfica, Martínez Guerrero rechaza emular la crudeza de las imágenes que publica la prensa nacional, toda vez que la dinámica creativa involucra una resignificación formal y conceptual de las imágenes, como señala su testimonio:

Al tratar los temas que manejo, trato de escapar de esta salida fácil que se tiene a la hora de reciclar gráficamente lo que se ve. A la hora de emular como una nota roja. Se trata de ver los casos más coherentes, más simbólicos. No reproducir la crudeza obvia, como referencial, sino una situación un poco más trascendente. Estoy manejando temas que últimamente también se han manejado mucho: los temas de la violencia, del poder, del manejo de la legitimidad. Pero estoy manejando estos temas lejos de la teoría, de forma más presencial. Pues, terminas empapado de todo lo que ves o lo que vives. Pues, a la hora de querer registrarlo plásticamente no solamente pasas una imagen a la plancha, sino que pasa por todo un proceso que está también permeado por todo lo que vemos (comunicación personal, 28 de junio de 2017). 


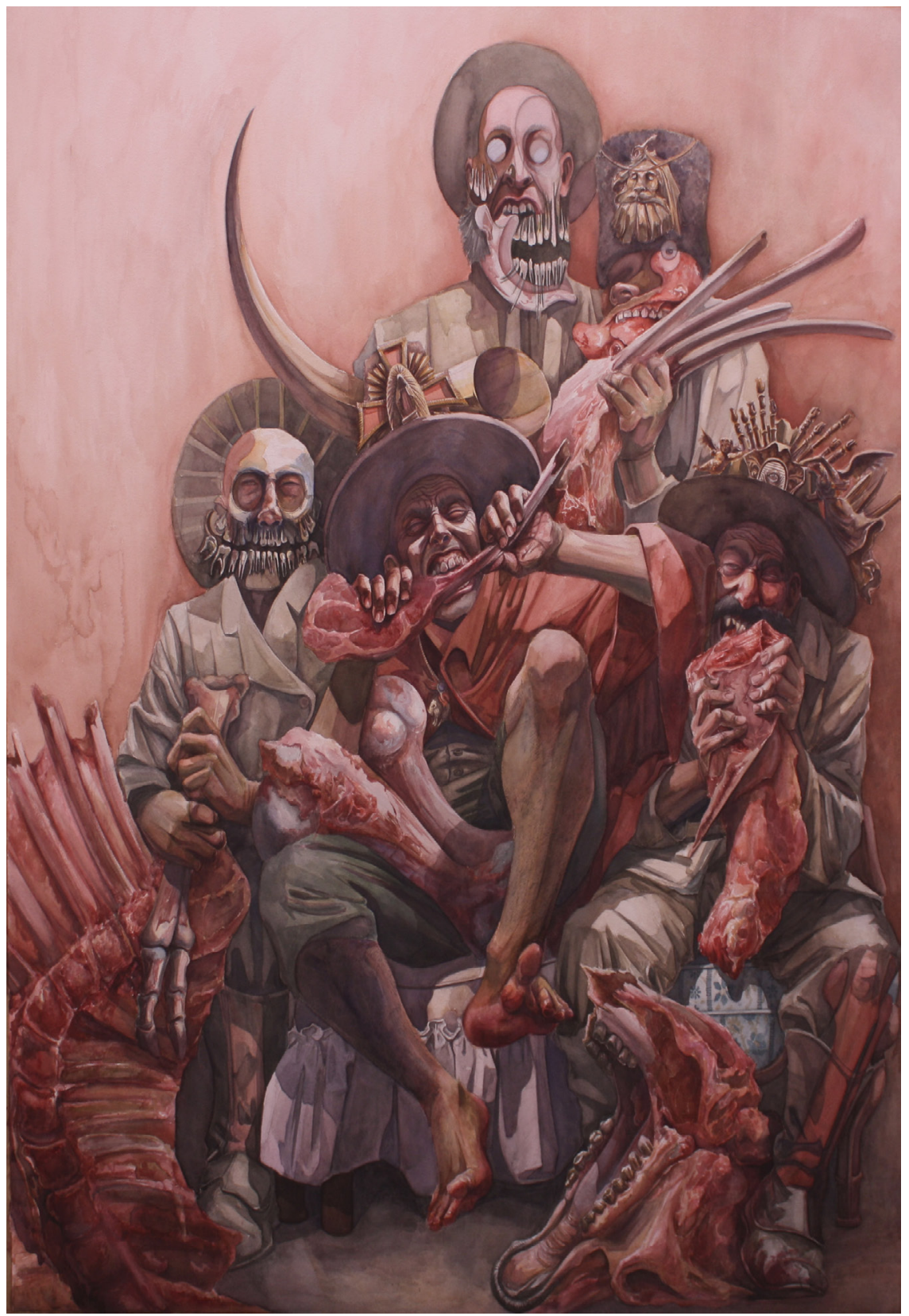

Figura 1. Emiliano Martínez Guerrero (2016). "Manducadores", acuarela, $138 \times 112 \mathrm{~cm}$. 
En su obra Leviatán. El festín de los hegemoniacos, (aguafuerte sobre lámina negra, $50 \times 60 \mathrm{~cm}, 2013$ ), Martínez Guerrero formula una metáfora de la guerra y los aparatos de coerción del Estado. En primer plano, se advierte la espalda de un personaje que se ocupa de capturar, con una antigua cámara fotográfica, la imagen de un conjunto de personajes que portan trajes militares de distintas épocas, desde los que se usaban en la Revolución Mexicana hasta los más actuales. Detrás del conjunto de personajes, están representados los tentáculos de un pulpo sobre la gigantesca cabeza de un personaje ensangrentado. En la parte inferior de la composición visual se ubica un pequeño recuadro donde un oficial militar posa frontalmente y realiza el saludo castrense. La figura se acompaña del texto: "Por tu seguridad".

La connotación simbólica del relato gráfico remite al discurso estatal que justifica la guerra mediante la figura protagónica del enemigo, como ocurrió, durante el gobierno de Felipe Calderón, quien prometió el eficaz combate al narcotráfico a través de la militarización del país. Hasta la actualidad, esta estrategia ha sido un fracaso que ha ensangrentado la vida pública e incrementado la violencia terrorista del narcotráfico. En esta perspectiva, el artista señala:

En la obra Leviatán, la bestia marina, hablo de la construcción del enemigo. Para la existencia del Estado es necesario la construcción del enemigo absoluto. Para que exista un sentido de comunidad artificial, como lo es el Estado, se necesita un gran relato, donde hay enemigos. Bajo esta lógica, Leviatán trata sobre la construcción del enemigo absoluto, la existencia del pueblo en oposición a éste y el montaje de los grandes relatos. (Martínez Guerrero, comunicación personal, 28 de junio de 2017).

Hasta la actualidad, el discurso gubernamental justifica la militarización del país y el heroísmo del Ejército mexicano a través de su guerra contra los narcotraficantes. En esta perspectiva, Martínez Guerrero recrea plásticamente la idealización de la guerra, como señala al referirse a Leviatán:

Los personajes funcionan más como conjuntos, representan esta idealización de la violencia oficial. Por ejemplo, las fotografías de los soldados de la Revolución Mexicana, las fotografías apropiadas de los revolucionarios, ahora ya, pueden exhibirse, porque la Revolución Mexicana es parte del discurso oficial. Quise hacer esta demostración de fuerza, cómo se presenta a estos señores de la guerra míticos: una interpretación a nivel social de la violencia (comunicación personal, 28 de junio de 2017).

Cabe subrayar la connotación simbólica del relato gráfico, al aludir a la gestión de la muerte que impone el aparato político:

Esa muerte, que se fundaba en el derecho del soberano a defenderse o a exigir ser defendido, apareció como el simple envés del derecho que posee el cuerpo social de asegurar su vida, mantenerla y desarrollarla. Sin embargo, nunca las guerras fueron tan sangrientas como a partir del siglo XIX e, incluso salvando las distancias, nunca hasta entonces los regímenes habían practicado sobre sus propias poblaciones holocaustos semejantes. Pero ese formidable poder de muerte -y esto quizá sea lo que le da una parte de su fuerza y del cinismo con que ha llevado tan lejos sus propios lími- 


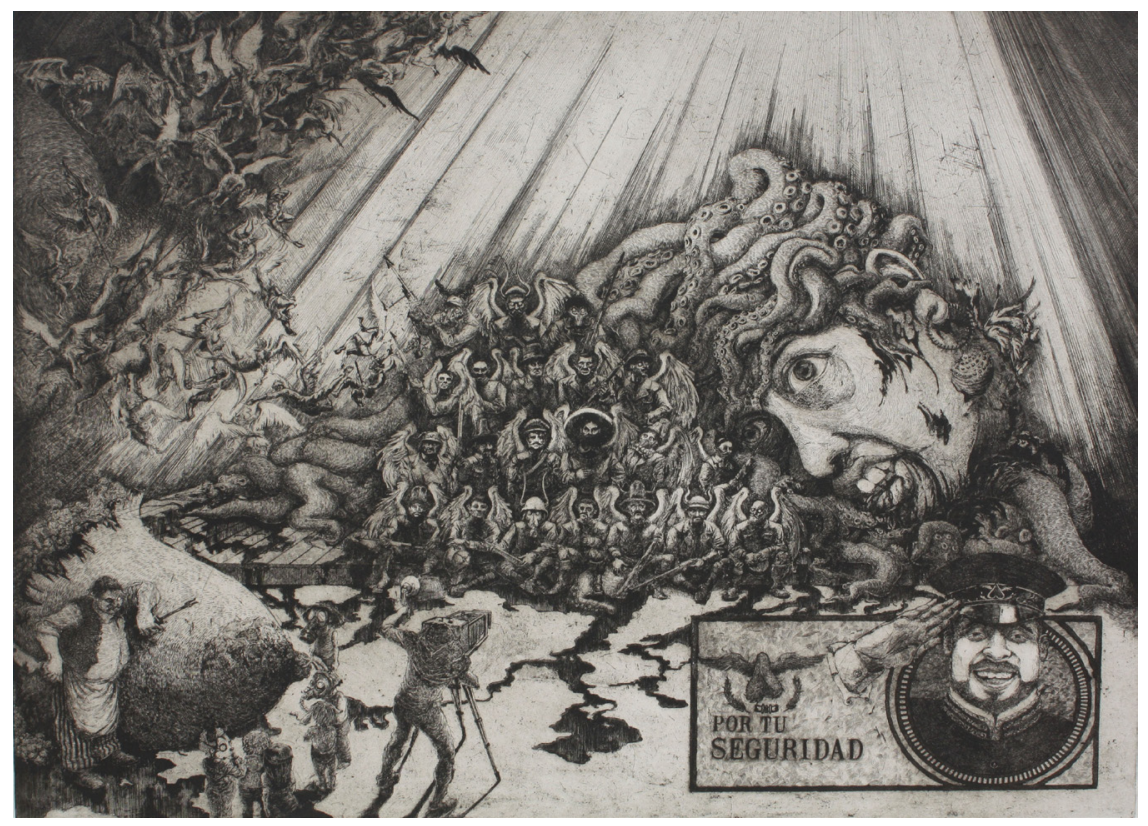

Figura 2. Emiliano Martínez Guerrero (2013). Leviathán / El festín de los hegemoniacos, aguafuerte sobre lámina negra, $50 \times 60 \mathrm{~cm}$.

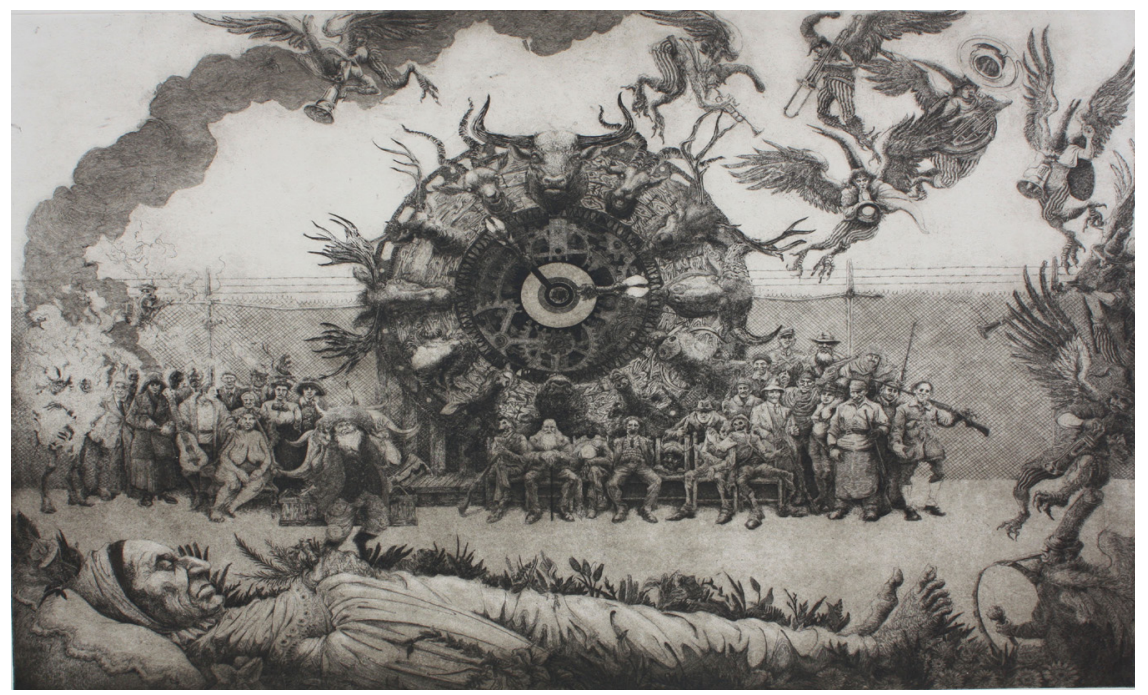

Figura 3. Emiliano Martínez Guerrero (2014). Behemoth / Los caminos de Dios, aguafuerte sobre lámina negra. $60 \times 90 \mathrm{~cm}$. 
Panambí n. 7 Valparaíso dic. 2018 ISSN 0719-630X. 17-36. DOI: 10.22370/panambi.2018.7.1136.

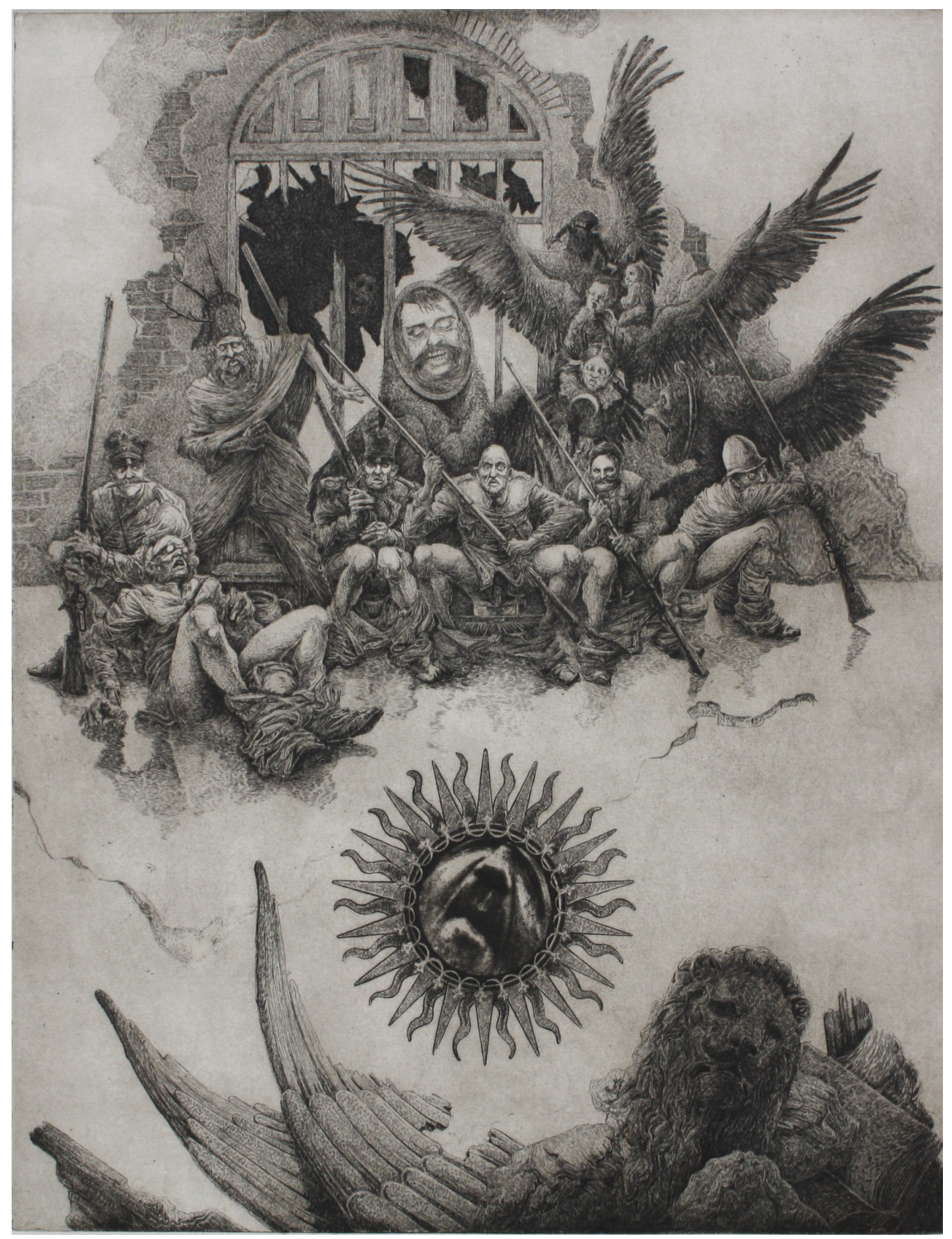

Figura 4. Emiliano Martínez Guerrero (2015), "Delirio", aguafuerte sobre lámina negra, $60 \times 48 \mathrm{~cm}$. 
tes- parece ahora como el complemento de un poder que se ejerce positivamente sobre la vida, que procura administrarla, aumentarla, multiplicarla, ejercer sobre ella controles precisos y regulaciones generales. Las guerras ya no se hacen en nombre del soberano al que hay que defender; se hacen en nombre de la existencia de todos; se educa a poblaciones enteras para que se maten mutuamente en necesidad que tienen de vivir. Las matanzas han llegado a ser vitales. Fue en tanto que gerentes de la vida y la supervivencia, de los cuerpos y la raza, como tantos regímenes pudieron hacer tantas guerras, haciendo matar a tantos hombres (Foucault, 1998: 82).

En la actual producción artística mexicana, la obra de Martínez Guerrero destaca no sólo por su eficacia simbólica y sus cualidades técnicas, sino también por su interpretación gráfica de la violencia terrorista del narcotráfico, que se centra en la condición de los victimarios y la praxis decadente del Estado mexicano.

Finalmente, cabe concluir que, desde la década de los 1920 hasta la actualidad, los artistas mexicanos han representado e interpretado el conflicto político y la violencia social en tres de sus modalidades: revolucionaria, de Estado y terrorista. Recurrentemente, las obras artísticas han constituido un recurso de denuncia social en distintos contextos históricos paradigmáticos del conflicto político mexicano. Tanto el muralismo mexicano como el Taller de Gráfica Popular justificaron la violencia defensiva y revolucionaria de las víctimas de las injusticias políticas, económicas, sociales, a través de la ideología marxista. En el contexto histórico de su época, marcado por la efervescencia cultural nacionalista que propiciaron la Revolución Mexicana y la política gubernamental reformista, los artistas gozaron de libertad de expresión ideológica y estética. Con estos antecedentes, el muralismo mexicano fue precursor en plantear una crítica al sistema capitalista y desarrollar el arte político e indigenista en América Latina.

Desde los años 1950 hasta los 1980, el sistema político mexicano se caracterizó por el autoritarismo presidencial y el control corporativista de los sectores laborales, así como por el régimen de partido único (Partido Revolucionario Institucional, PRI) que acotó las libertades democráticas en el país. En este contexto, se manifestó la represión gubernamental a los disidentes sociales que culminó con la masacre de estudiantes en 1968 y 1971. Es entonces que los artistas representaron e interpretaron la violencia de Estado a través de la gráfica y los lenguajes del arte conceptualista que, en ese momento, resultaban novedosos. Por ende, el arte político cobró impulso a través de las obras del movimiento estudiantil de 1968, del Grupo Proceso Pentágono y de los artistas José Antonio Hernández y Melecio Galván.

Actualmente, la obra gráfica de Emiliano Martínez Guerrero se destaca por interpretar simbólicamente la condición de deshumanización y crueldad que caracteriza la violencia terrorista que practican los grupos criminales del narcotráfico. Su discurso gráfico resulta sui géneris por apartarse de la tendencia de los artistas mexicanos que se centran en recrear, en sus obras, la condición de las víctimas de la violencia criminal. Ofrece un testimonio de la decadencia del Estado mexicano 
y su incapacidad de garantizar la convivencia social. En todos los casos y con suma valentía, los artistas han optado por denunciar, a través de sus obras, la violencia social imperante y la ineficacia del sistema político mexicano en la construcción del equilibrio democrático, en distintos periodos históricos.

\section{Referencias}

Arteaga Botello, N. (2009). Decapitaciones y mutilaciones en el México contemporáneo, Espacio Abierto, volumen 18(3), 463-486.

Arteaga Botello, N. (2003). El espacio de la violencia: un modelo de interpretación social. Sociológica, 18(52), 119-145.

Aquino, A. (1995). Melecio 1945-1982; un sentimiento y una visión de la violencia. Arte y violencia. México: Universidad Nacional Autónoma de México, 339-362.

Diario Respuesta (2011, 17 de abril). Crueldad sin límite. Diario Respuesta, 13.

Diaz, G. L. (2017, 22 de julio). Entre el infierno y la esperanza. Proceso, (2122), 22-27.

Diéguez Caballero, I. (2018). Encarnaciones poéticas. Cuerpo, arte y necropolítica. Athenea Digital, 18(1), 203-219. DOI: https://doi.org/10.5565/rev/athenea.2250.

Driben, L. (1992). Melecio Galván el artista secreto. México: Universidad Nacional Autónoma de México.

Foucault, M. (2002). Vigilar y castigar. Buenos Aires: Siglo XXI.

Foucault, M. (2001). Defender la sociedad. Buenos Aires: FCE.

García, P. (2016). Expediente Grupo Proceso Pentágono. Políticas de la intervención 1969-1976-2015. México: MUAC, 20-58.

Híjar, A. (2018). TGP 80 años. México: Museo Nacional de la Revolución.

Marchán-Fiz, S. (1994). Del arte objetual al arte de Concepto. Madrid: Akal.

Martínez Guerrero, E. (2017, 28 de junio). Comunicación personal.

Mauleón de, H. (2018, 25 de julio). Entrevista con un sicario. El Universal, 15.

Morales, L. (1992). El Taller de Gráfica Popular y su vinculación con el realismo socialista. Arte y coerción. México: UNAM, 205-220.

Rodríguez Prampolini, I. (coord.) (2012). Muralismo Mexicano 1920-1940. Catálogo razonado I. México: FCE.

Prignitz-Poda, H. (1992). El Taller de Gráfica Popular en México, 1937-1977. México: INBA.

Rodríguez García, A. (2017, 22 de julio). Caso Meztli: la saña que terminó en asesinato. Proceso, (2122), 8-9. 
Tejeda, Armando (2018, 14 de mayo). Gráfica del 68 en México y Francia, arte al servicio de la protesta. La Jornada, 7.

Tibol, R. (1981). Historia general del arte mexicano. Época moderna y contemporánea. México: Hermes.

Urías Horcasitas, B. (2005). Retórica, ficción y espejismo: tres imágenes de un México bolchevique (1920-1940). Relaciones. Estudios de historia y sociedad, XXVI (101), 220-268. 